\title{
KEPEMIMPINAN VISIONER; DALAM MEMBANGUN BUDAYA ORGANISASI BERPRESTASI DI MAN 2 PROBOLINGGO
}

\author{
Muhammad Sugianto*
}

\begin{abstract}
The birth of organizational culture in Islamic educational institutions can not be separated from the typology of visionary leadership. Organizations are therefore defined as a rational tool for coordinating and controlling a group of people in the process of achieving goals. Leadership appears in the process by which a person directs, guides, influences and or controls the thoughts, feelings and behavior of others. In the world of education, especially Islamic education, leadership in an Islamic educational institution has a strategic position in bringing Islamic educational institutions in the direction desired by a leader. Therefore, both the bad image of Islamic educational institutions is determined by both the poor performance, ability and image of a leader in managing the organization. In relation to the influence of the leadership of an Islamic educational institution-the head of a madrasah-, visionary leadership is needed as a requirement to create the effectiveness and efficiency of educational institutions, especially Madrasah Aliyah Negeri 2 Probolinggo, improving the quality of madrassas and forming the image of Islamic educational institutions.
\end{abstract}

Keywords: Leadership Visionary and Organizational Culture

\section{A. Pendahuluan}

Dinamika perkembangan pendidikan Islam di Indonesia, secara signifikan telah memainkan perannya baik sebagai lembaga pendidikan Islam (al-haiah al ta'lim wa altarbiyah), pelayanan-bimbingan (al-haiah al ta'awuny wa al takafuly wal al ittijaahi) maupun perjuangan (al-haiah al-jihaadi li'izzi al-Islaami wal muslimin). Karena itu, potret pendidikan Islam -madrasah-terus mengalami perkembangan sesuai dengan harapan masyarakat dan keberadaannya tetap survive. Kondisi ini, tentu tidak lepas dari model kepemimpinan dan sistem organisasi yang dibangun ${ }^{1}$. Secara universal,budaya organisasi mengacu pada sekumpulan keyakinan hidup bersama dan tata hubungan serta berbagai asumsi yang secara eksplisit dapat diterima dan digunakan oleh keseluruhan anggota organisasi untuk menghadapi lingkungan luar dalam mencapai tujuan-tujuan organisasi. Dalam hal ini, budaya organisasi mempunyai pengaruh penting terhadap motivasi dalam diri setiap individu ${ }^{2}$. Demikian budaya organisasi bagi sebagian orang menyebut juga sebagai tradisi organisasi mengacu ke suatu system makna bersama yang

* Dosen Institut Ilmu Keislaman Zainul Hasan Genggong Probolinggo Jawa Timur email: muhsugianto@gmail.com

${ }^{1}$ Ahmad Fauzi, 'Membangun Epistemologi Pendidikan Islam Melalui Kepemimpinan Spiritual : Suatu Telaah Diskursif', (Empirisma STAIN Kediri, 24.2, 2015), h. 155-67.

2 Anthony-Darden-Bedford, Sistem Pengendalian Manajemen, Jilid 1, (Jakarta, Bina Rupa Aksara, 1992), h. 67. 
dianut oleh anggota-anggota yang membedakan organisasi itu dari organisasi-organisasi yang lain. Karena itu, jika diamati dengan lebih seksama, merupakan seperangkat karakteristik utama yang dihargai bahkan dicita-citakan oleh organisasi itu.

Budaya organisasi (organizational culture) jika diaplikasikan pada lingkungan menajemen organisasi maka lahirlah konsep budaya manajemen. Secara spesifik apabila budaya organisasi diaplikasikan pada lingkungan manajemen organisasi madrasah, maka lahirlah konsep budaya manajemen madrasah. Bagus tidaknya budaya manajemen madrasah banyak ditentukan oleh kepemimpinan yang banyak memebrikan sumbangan terhadap terwujudnya tujuan-tujuan kelompok atau golongan dalam memenuhi tujuan yang ingin dicapai ${ }^{3}$. Kepemipinan tampak dalam proses dimana seseorang mengarahkan, membimbing, mempengaruhi dan atau menguasai pikiran-pikiran, perasaan-perasaan atau tingkah laku orang lain. Dalam dunia pendidikan, khususnya pendidikan Islam, kepemimpinan pada suatu lembaga pendidikan Islam mempunyai posisi yang strategis dalam upaya membawa lembaga pendidikan Islam ke arah yang dinginkan oleh seorang pemimpinnya. Baik buruknya citra lembaga pendidikan Islam sangat ditentukan oleh baik buruknya kinerja, kemampuan dan citra dari seorang pemimpin dalam mengelola organisasi kelembagaannya. Sehubungan dengan besarnya pengaruh pimpinan pada suatu lembaga pendidikan Islam -kepala madrasah-, dalam hal ini maka diperlukan kepemimpinan visioner sebagai persyaratan untuk menciptakan efektivitas dan efisiensi lembaga pendidikan, khususnya Madrasah Aliyah Negeri 2 Probolinggo, peningkatan kualitas dan mutu madrasah serta pembentukan citra lembaga pendidikan Islam dan lain sebagainya.

\section{B. Pembahasan}

\section{Kepemimpinan dan Budaya Organisasi Madrasah}

Selama ini banyak orang yang beranggapan bahwa sebuah tim tidak ada bedanya dengan kelompok. Padahal antara keduanya memiliki perbedaan yang sangat signifikan. Dalam sebuah kelompok biasanya hubungan yang dibangun hanya sebatas berinteraksi untuk membagi informasi dan mengambil keputusan untuk membantu tiap anggota dalam bidang tanggungjawabnya. Sedangkan tim kerja merupakan kelompok yang upaya-upaya individunya menghasilkan suatu kinerja yang lebih besar daripada jumlah dari masukan-masukan individual. ${ }^{4}$ Kesalahan pandangan ini tentu saja akan berimplikasi terhadap kinerja tim dalam menjalankan tugas-tugasnya. Sehingga tidak jarang masih banyak tim-tim yang dibangun tidak bisa menjelma menjadi sebuah tim yang solid karena itu dalam

${ }^{3}$ Ahmad Fauzi, 'Manajemen Pendidikan Islam Di Pesantren; Berbasis Kearifan Lokal Kajian Fenomenologis', (Seminar Nasional Pendidikan, Fakultas Ilmu Pendidikan Universitas Negeri Malang Sinergitas Keluarga, Sekolah Dan Masyarakat Dalam Penguatan Pendidikan Karakter, Malang, 2017), pp. 51-62.

${ }^{4}$ Stephen P. Robbins, Prilaku Organisasi: Konsep, Kontroversi, Aplikasi, Jilid 1, (Jakarta, PT. Prehallindo, 1996), h.325. 
pelaksanaannya masih cenderung bersifat kelompok. Perbedaan lebih jelas antara keduanya, menurut Robbins, ${ }^{5}$ dapat dilihat pada matrik berikut.

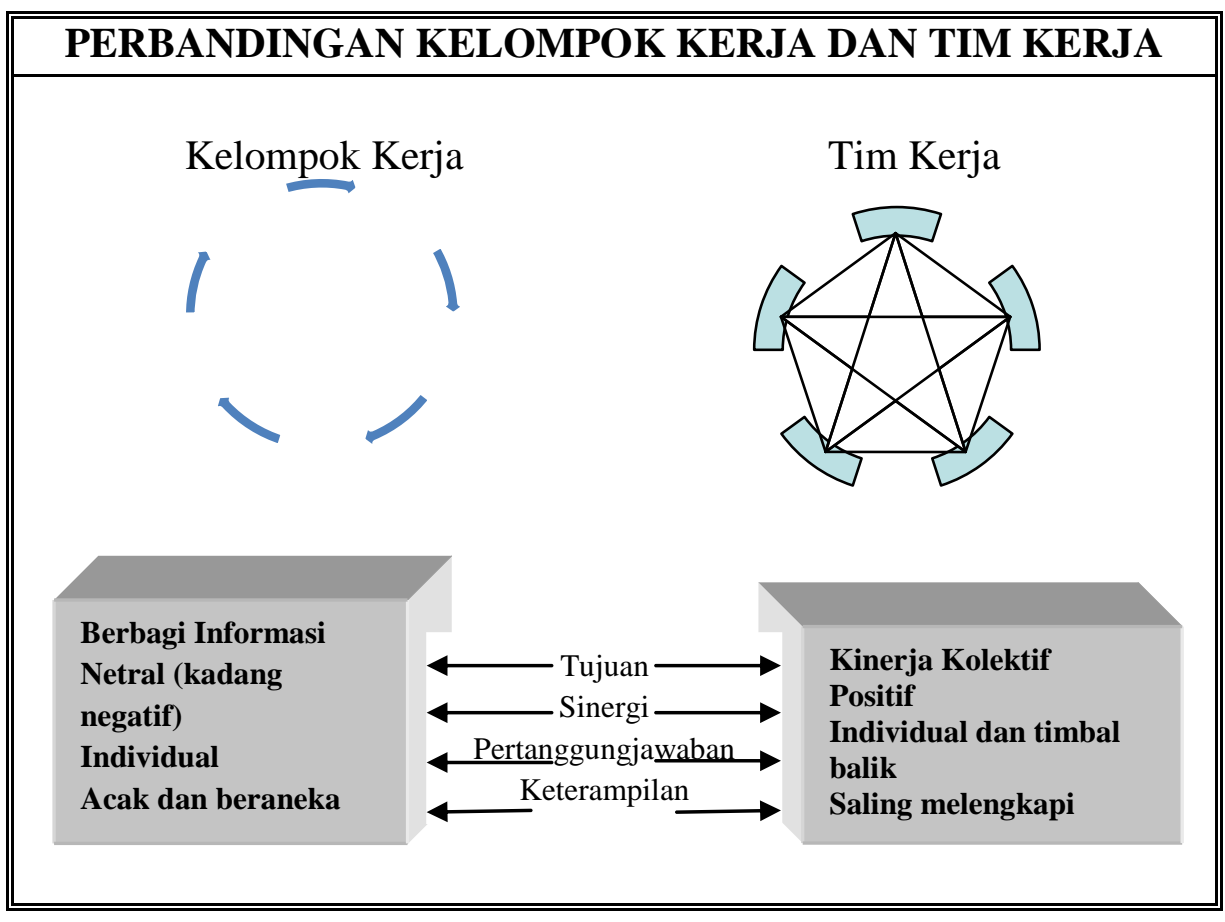

Berdasarkan matrik di atas tampak jelas bahwa kinerja antara kelompok dengan tim sama sekali berbeda bahkan cenderung bertolak belakang. Para pemimpin atau manajer dalam sebuah organisasi, kebanyakan sudah merasa puas jika berhasil membangun sebuah kinerja kelompok. Hal ini sering terjadi karena mereka tidak berpikir melampaui apa yang telah dicapai dengan apa yang seharusnya dapat dihasilkan dalam keadaan yang tidak terlalu berbeda. Padahal jika mereka bisa membentuk sebuah kinerja tim dalam organisasi yang dipimpinnya, maka persoalan apapun yang dihadapi oleh organisasi akan lebih mudah diatasi. Selain itu, dengan kinerja tim produktivitas akan meningkat, waktu yang digunakan bisa lebih efektif, dan biaya pun bisa ditekan pengeluarannya ${ }^{6}$.

Demikian, berkaitan dengan pembinaan tim, seorang manajer hendaknya mempertimbangkan kegiatan yang mencakup penetapan tujuan, pengembangan hubungan antarpribadi di antara anggota tim, analisis peran peran untuk memperjelas peran dan tanggung jawab anggotanya. Pengembangan tim dapat memberi tekanan atau menyisihkan aktivitas-aktivitas tertentu, tergantung pada usaha pengembangan dan masalah-masalah tertentu yang dihadapi tim. Akan tetapi pada dasarnya pengembangan tim mencoba untuk mempergunakan interaksi yang

${ }^{5}$ Stephen P. Robbins, Prilaku Organisasi: Konsep, Kontroversi,............, h.35.

${ }^{6}$ Ahmad Fauzi, 'Diskursus Pemikiran Dan Model Pengembangan Budaya Organisasi Noble Industry Di Lembaga Pendidikan Islam', (Studi Islam Madinah IAI Tabah, 16, Pendidikan Islam, 2016), h. 22. 
tinggi di antara anggota kelompok untuk meningkatkan kepercayaan, keterbukaan. ${ }^{7}$ Seorang pemimpin yang menginginkan terjadinya efektifitas dalam organisasi harus menempatkan kerjasama tim pada posisi utama. Selain itu seorang pemimpin juga harus memahami cara mentransformasikan kelompok agar menjadi sebuah tim yang produktif. Jika pemimpin tidak mengutamakan kerjasama tim serta tidak mampu mentransformasikan kelompok menjadi sebuah tim yang produktif, maka efektifitas tidak akan pernah terjadi. Kerjasama tim memerlukan usaha untuk mengembangkannya, dan upaya terus menerus untuk memeliharanya agar hasil yang diperoleh sebanding. ${ }^{8}$

Dalam upaya membangun tim yang produktif, seorang pemimpin tim, menurut Maddux, seyogyanya melakukan hal-hal berikut: a) memiliki visi tentang apa yang dapat dicapai seseorang dalam sebuah tim, dapat berbagi visi dan mengambil tindakan yang cepat. b) bersikap proaktif dalam setiap relasi, yaitu menunjukkan gaya pribadi dan dapat membangkitkan kegairahan dalam bertindak, serta menginspirasikan kerja tim dan membangun suasana yang saling mendukung. 3) membuat orang lain terlibat dan memiliki ikatan, serta memudahkan orang lain melihat kesempatan dalam kerja tim, memungkinkan orang lain untuk berprestasi. 4) mencari beberapa orang yang mau maju dan dapat bekerja secara konstruktif dengan anggota tim lainnya, merasa memiliki peran untuk mendorong dan memudahkan prilaku sosial individu. 5) memandang pemecahan masalah sebagai tanggung jawab para anggota tim. 6) berkomunikasi secara utuh dan terbuka. 7) menengahi konflik sebelum menjadi destruktif. 8) mengupayakan agar kemajuan perorangan dan tim dapat dikenali pada saat yang tepat dan benar. 9) menjaga komitmen dan sebaliknya menmgharapkan hal yang sama dari orang lain.

\section{Standarisasi dan Kompetensi Kepemimpinan Madrasah}

Kepala madrasah sebagai pelaksana kepemimpinan pendidikan di madrasah, khususnya Madrasah Aliyah harus memiliki kemampuan dan keterampilan yang dapat dipraktekkan dalam kehidpan sehari-hari. Di bawah ini terdaftar item-item yang menentukan kesuksesan kepala Madrasah Aliyah sebagai pemimpin pendidikan. Daftar ini merupakan pemikiran dari para administrator yang baik dalam wujud tindak laku. Daftar ini juga merupakan barometer kebaikan kepemimpinan kepala madrasah dan menggambarkan tugas-tugas dan peranan kepala madrasah dalam melaksanakan kepemimpinan pendidikan.Sebelum memasuki pada tahap standar kompetensi yang harus di miliki oleh kepala Madrasah Aliyah, ada tiga hal yang perlu diperhatikan oleh setiap kepala madrasah, sebagai pemimpin lembaga pendidikan Islam diantaranya : 1) seorang pemimpin memerlukan kemampuan berfikir secara fleksibel dalam organisasi; melihat organisasi dari berbagai sudut pandang; menyesuaikan gaya kepemimpinan agar

\footnotetext{
${ }^{7}$ Stephen P. Robbins, Prinsip-Prinsip Prilaku Organisasi, (Jakarta, Erlangga, 2002), h. 317.

${ }^{8}$ Robert B. Maddux, Team Building, alih bahasa oleh Kristiabudi P. Hananto, Team Building: Terampil Membangun Tim Handal, (Jakarta, Erlangga, 2011), h. 11.
} 
cocok dengan isu-isu yang sedang tumbuh. 2) pemimpin perlu mengembangkan kecakapannya untuk melihat organisasi sebagai bentuk organisk dengan kebutuhan, peranan, kewibawaan dan symbol-simbol yang secar bisnis bercampur untuk membantu arah dan memebentuk perilaku individu. 3) pemimpin kepala madrasah Aliyah harus diperkenalkan konsep - frame - kecakapan untuk melihat organisasi melalui lensa yang berbeda-beda, yaitu ; fleksibel dalam pemikrian, menganjurkan fleksibel ke dalam tindakan dan kecakapan memainkan peranan yang perlu di dalam situasi tanpa mengorbankan nilai-nilai dasar

Berdasarkan ketiga tersebut, perlu diperhatikan oleh para pemimpin, maka profil seorang pemimpin madrasah yang disebut sebagai kepala madrasah yang berhasil adalah pemimpin yang mampu menciptakan dan menopang satu keseimbangan di antara beberapa hal yang ekstrem yaitu ; a) mengetahui bagaimana pemimpin berpihak, mengetahui apa yang diharapkan oleh organisasi. b) mampu berpikir kreatif tentang bagaimana membuat sesuatu terjadi dan dapat mengembangkan strategi, memberikan respon terhadap realitas organisasi. c) para pemimpin adalah pujangga yang filosofis, pemikir yang pemain, seorang negoisator yang dapat memberi dan menerima pelaku lain serta kepentingan-kepentingan lain di dalam membentuk suatu arah yang telah direncanakan. ${ }^{9}$ Berangkat dari hal tersebut, maka dapat dirumuskan tentang bagaimana standar kompetensi yang harus dimiliki oleh tiap kepala madrasah yang akan memimpin pada suatu lembaga pendidikan tingkat Madrasah Aliyah Negeri 2 Probolinggo. Kompetensi dasar tersebut merupakan pra syarat bagi seorang pemimpin, yang harus dimiliki oleh masing-masing individu yang akan menjadi kepala Madrasah Aliyah Madrasah Aliyah Negeri 2 Probolinggo. Diantara standar kompetensi yang harus di miliki oleh personal kepala madrasah, menurut Muhaimin ${ }^{10}$ antara lain; 1) General life skill, yang mencakup: beberapa hal yaitu: a) Personal skill, kecakapn personal atau kecakapan mengenal diri meliputi; kesadaran sebagai mahluq Tuhan, kesadaran akan ekstistensi diri, kesadaran akan potensi diri, b) Thinking skill, kecakapan berfikir, meliputi; kecakapan menggali informasi dan menemukan informasi, kecakapan mengolah informasi, kecakapan dalam memecahkan masalah. c) Social skill, meliputi; kecakapan komunikasi lisan, kecakapan komunikasi tertulis, kecakapan bekerja sama. 2) Spesific life skill, mencakup; Academic skill, kecakapan akademis meliputi; mengidentifikasi variable, merumuskan hipotesis dan melaksanakan penelitian Vocational skill (kecapan vocational) atau ketrampilan kejuruan, yakni keterampilan yang dikaitkan dengan pekerjaan tertentu yang terdapat dilingkungan masyarakat.

Berbagai kompetensi tersebut merupakan kerangka dasar yang harus dimiliki dalam rangka menciptakan proses pelaksanaan kependidikan yang efektif dan

9 Wahjosumidjo, Kepemimpinan Kepala Sekolah Tinjauan Teoritik dan Permasalahannya, (Jakarta, PT Raja Grafinco Persada, 2002), h. 78-79.

${ }^{10}$ Muhaimin, Pengembangan Kurikulum Pendidikan Agama Islam di Sekolah, Madrasah dan Perguruan Tinggi, (Jakarta, PT Raja Grafindo Persada, 2005), h. 266. 
efisien, mewujudkan tujuan dari lembaga pendidikan yang dipimpinnya, memperbaiki dan mengangkat mutu, kualitas dan citra Madrasah Aliyah Negeri 2 Probolinggo, dan dapat mengcover terhadap berbagai kebutuhan konsumen yang berkaitan dengan lembaga pendidikan yang dipimpinnya. Dari sini dapat dijabarkan, bahwa pada personal kepala dibutuhkan kompetensi dan skill yang bersifat universal dan kompetensi atau skill yang bersifat khusus yang harus dimiliki. Kompetensi atau skill yang bersifat universal tersebut, meliputi : keahlian atau kemampuan dasar, sifat atau watak; sedang persyaratan khusus yang diperlukan adalah berbagai kemampuan: seperti penguasaan terhadap tugas dan keterampilan profesional, pelatihan dan pengalaman professional dan kompetensi administrasi dan pengawasan $^{11}$.

Dari ciri-ciri kepemimpinan yang bersifat universal dan ciri-ciri khusus, sesuai dengan tuntutan spesifikasi jabatan kepala madrasah melahirkan standar kompetensi kepemimpinan kepala madrasah dalam arti untuk diskripsi yang mengungkapkan tentang kecakapan, kepribadian, dan karier dalam hidup (riwayat pekerjaan) secara garis besar seorang kepala madrasah. Keahlian atau kemampuan dasar; kemampuan dasar ini, yaitu sekelompok kemampuan yang harus dimiliki oleh tingkat pemimpin apapun, yang mencakup; a) Technical skills, kecakapan spesifik tentang proses, tekhnik-tekhnik, atau merupakan kecakapan khusus dalam menganalisis hal-hal yang khusus dan penggunaan fasilitas, peralatan, serta teknikteknik pengetahuan yang spisifik. b) Human skills, Kecakapan pemimpin untuk bekerja secara efektif sebagai anggota kelompok dan untuk menciptakan usaha kerja sama di lingkungan kelompok yang dipimpinnya. Apabila dalam technical skills menunjukkan kecakapan yang berhubungan dengan barang, sebaliknya human skills menunjukkan ketrampilan yang berkaitan dengan orang atau manusia, yang indikatornya sebagai berikut; mampu mempengaruhi orang lain, mampu melihat dirinya sendiri atau sikapnya, mampu menciptakan satu lingkungan dimana pemimpin dan bawahannya merasa yakin, suasana memungkinkan bekerja sama secra harmonis dan produktif, mampu menjadi komunikator dan pemimpin yang efektif, mampu berhubungan dengan orang lain dan menciptakan lingkungan yang saling percaya, keterbukaan dan rasa hormat bagi individu. c) Conceptual skills, yang memiliki indicator : Kemampuan seorang pemimpin melihat organisasi sebagai satu keseluruan, Mengetahui bagaimana fungsi organisasi yang bernmacam-macam saling bergantung satu sama lain, dan bagaimana pertumbuhan yang terjadi, pada satu bagian tertentu akan berpengaruh terhadap bagian yang lain, mengkoordinasikan dan mengintegrasikan seluruh aktivitas, kepentingan dan perseosi dari individu dan kelompok ke dalam organisasi sebagai totalitas ${ }^{12}$.

11 Ahmad Fauzi, 'Human Resource Management Dalam Meningkatkan Mutu Dosen PTKIS', (At-Ta'lim INZAH Genggong Probolinggo, 4, 1.Pendidikan Islam, 2018), h. 21-34.

${ }^{12}$ Ahmad Fauzi, Persepsi Barakah Di Pondok Pesantren Zainul Hasan Genggong; Perspekstif Interaksionalisme Simbolik, (E-Jurnal Al-Tahril IAIN Ponorogo, 17 Islam Ortodoksi Heterrodoksi, 2017), h. 105-32. 


\section{Kepemimpinan Visioner dalam Membangun Madrasah Berprestasi}

Berbicara tentang peranan kepala madrasah dan kaitannya dengan peningkatan kinerjanya, maka prinsip-prinsip dan praktek kepemimpinan ini hendaknya dikaitkan dengan peranan kepala madrasah dan kedudukan pimpinan lainnya yang relevan dan peranan kepemimpinan khusus dalam menggerakkan para pelaksana yang meliputi hubungan dengan staff, siswa, orang tua siswa, dan orangorang lain di luar komuniti tempat madrasah itu berada ${ }^{13}$. Dalam sejarah pertumbuhan peradaban manusia banyak menunjukkan bahwa salah satu faktor yang dapat menentukan keberhasilan organisasi adalah kuat tidaknya sebuah kepemimpinan. Kegagalan dan keberhasilan suatu oganisasi banyak ditentukan oleh pemimpin karena pemimpin merupakan pengendali dan penentu arah yang hendak ditempuh oleh organisasi menuju tujuan yang akan dicapai. Hal ini sejalan dengan dengan apa yang dikemukakan Siagian ${ }^{14}$ bahwa arah yang hendak ditempuh oleh organisasi menuju tujuan harus sedemikian rupa hingga mengoptimalkan pemamfaatan dari segala sarana dan prasarana yang tersedia. Arah yang dimaksud tertuang dalam strategi dan taktik yang disusun dan dijalankan oleh organisasi yang bersangkutan. Perumus serta penentu strategi dan taktik adalah pemimpin dalam organisasi tersebut ${ }^{15}$.

Sebagai pemimpin pendidikan, kepala madrasah menghadapi tanggung jawab yang berat, untuk itu ia harus memiliki persiapan memadai dalam melaksanakan pekerjaannya ${ }^{16}$. Pekerjaan pemimpin pendidikan adalah menstimulir dan membimbing pertumbuhan guru-guru secara continue sehingga mengenal dan mampu melaksanakan dengan lebih baik segenap tugas pengajarannya sehingga mereka akhirnya mampu menstimulir dan membimbing murid-murid untuk dapat berpartisipadi di dalam masyarakat demokratis. Kepala madrasah harus mampu menciptakan situasi belajar mengajar yang baik. Karena itu ia harus mampu mengelola (school plant), pelayanan-pelayanan khusus madrasah, dan fasilitsfasilitas pendidikan sehingga guru dan murid-murid dapat memperoleh kepuasan menikmati kondisi kerja; mengelola personalia pengajar dan murid; membina kurikulum yang memenuhi kebutuhan dan mengelola catatan-catatan pendidikan. Kesemuanya diharapkan agar ia dapat memajukan program pengajaran di madrasahnya.

Dalam menghadapi kehidupan terbuka dalam abad 21 dengan masalahmasalah globalnya, menurut Tilaar $^{17}$ diperlukan pemimpin-pemimpin yang sesuai yang disebut pemimpin profesional; pemimpin yang bukan hanya menguasai kemampuan dan ketrampilan untuk memimpin tetapi juga dituntut dari padanya dua

\footnotetext{
${ }^{13}$ Piet A. Sahertian, Dimensi Aministrasi Pendidikan, (Surabaya, Usaha Nasional, 1994), h21.

${ }^{14}$ Sondang P. Siagian, Manajemen Strategik, (Jakarta, Bumi Aksara, 2004), h 49.

15 Ahmad Fauzi, 'Model Manajemen Pendidikan Islam; Telaah Atas Pemikiran Dan Tindakan Sosial', (At-Ta'lim INZAH Genggong Probolinggo, 4, Pendidikan Islam, 2017), h. 1-16.

${ }^{16}$ Hendiyat Soetopo \& Wasty Soemanto, tt, Kepemimpinan dalam Pendidikan, (Surabaya, Usaha Nasional, 2011), h 38.

${ }^{17}$ H.A.R Tilaar, Paradigma Baru Pendidikan Nasional, (Jakarta, Rineka Cipta, 2000), h 159.
} 
hal, yaitu sebagai berikut ; a) pemimpin yang dapat mengejawantahkan nilai-nilai Islam di dalam sistem pendidikan Islam, dan b) pemimpin yang memiliki dan menguasai ilmu pengetahuan dan teknologi sesuai dengan perkembangan zaman. Demikian salah satu unsur dari kepemimpinan pendidikan lainnya ialah gaya kepemimpinan yang demokratis ${ }^{18}$. Gaya ini telah melekat di dalam kehidupan pendidikan Islam, oleh sebab itu perlu dilestarikan dan disesuaikan dengan tingkat kecerdasan rakyat. Kepemimpinan yang demokratis pada masa yang lalu tentunya berbeda dengan kepemimpinan demokratis di dalam masyarakat yang sudah berkembang. Semakin tinggi tingkat pendidikan rakyat, semakin tinggi pula partisipasinya di dalam kehidupan bersama. Oleh sebab itu kepemimpinan pendidikan Islam di dalam era dewasa ini haruslah seorang yang mempunyai pandangan yang luas sehingga dapat mengakomodasikan berbagai pikiran dan pendapat masyarakat yang semakin dewasa, dengan demikian pemimpin masa depan lembaga pendidikan haruslah pemimpin visioner ${ }^{19}$.

Pemimpin visioner adalah pemimpin yang memiliki dan selalu berorientasi ke depan, apa yang ingin diwujudkan di masa depan dari realitas yang sedang dihadapi. Pemimpin yang visioner itu penting dalam menentukan hidup matinya lembaga pendidikan. Ini dapat dipahami dari alasan bahwa (a) adanya perubahan lingkungan yang cenderung sulit diramalkan, sulitnya membuat ramalan menyebabkan rencana strategis organisasi sering tidak cocok lagi dengan lingkungan yang sudah berubah; dan (b) rencana strategis organisasi akhirnya digantikan oleh visi organisasi yang lebih fleksibel dalam menghadapi perubahan lingkungan. Demikian, untuk menghadapi perubahan-perubahan yang sulit diramalkan tersebut dan upaya menyususn visi baru yang lebih fleksibel, menurut Darmayanti diperlukan pemimpin masa depan yang visioner, yaitu; (1) mendorong setiap organisasi untuk mengidentifikasi masalah dan kemudian memecahkannya; (2) memaksimalkan energi dengan cara; keluar dari situasi status quo dan tidak terlalu bersikap kompromistis; menghasilkan keputusan yang berkualitas; mencapai target hasil yang maksimal, dengan teknik dan metode yang sama sekali baru; (3) mengolah data dan informasi dengan cepat; (4) menyajikan informasi yang benar dan mudah dicerna; (5) mahir dalam berkomunikasi; (6) mengajak anggota organisasi untuk berpikir dan bertindak menurut agenda kegiatan mereka; (7) mengolah, melatih, dan menggunakan intuisi untuk mengambil keputusan ${ }^{20}$.

Pemimpin visioner, menurut Darmayanti perlu melakukan lima peran sebagai berikut; pertama, peran merumuskan visi (the vision role); kedua, peran menjalin hubungan (the relationship roles); ketiga, peran mengendalikan (the control role); keempat, peran melakukan dorongan (the encourage role); kelima,

${ }_{18}^{18}$ Ngalim Purwanto, Administrasi Pendidikan, (Jakarta, Mutiara Sumber Widya, 1991), h. 48.

19 Fauzi Ahmad, Pendidikan Inklusif Berbasis Kearifan Lokal Dalam Praktik Sosial Di Pesantren Zainul Hasan Genggong Probolinggo Jawa Timur, (Proceedings Ancoms 1St Annual Conference For Muslim Scholars, 2.110, 2017), h. 715-25.

${ }^{20}$ Tri Darmayanti, dalam In Service Training $M T s / M i$, (Depag RI Basic Education Project (BEP) PPIM IAIN Jakarta, 2011), h 202. 
Peran sebagai pemberi informasi (the information role) ${ }^{21}$. Beberapa peran dan tanggung jawabnya terhadap proses kependidikan di lingkungan yang dipimpinnya, dapat diketahui bahwa semakin tinggi kepemimpinan yang diduduki seseorang dalam organisasi kependidikan, nilai dan bobot strategik dari keputusan yang diambilnya semakin besar. Sebaliknya semakin rendah kedudukan seseorang dalam suatu organisasi kependidikan, keputusan yang diambilnya pun lebih mengarah kepada hal yang operasional. Terlepas dari keputusan yang diambil, apakah pada kategori strategik, taktis, teknis, atau operasional, semuanya tergolong pada penentuan arah dari perjalanan kepala madrasah merupakan top leader dalam suatu lembaga pendidikan. Kebijakan yang diputuskan merupakan hal yang strategi dalam keberhasilan madrasah. Kepala madrasah seharusnya orang yang memiliki kecerdasan, kekreatifan, dan visi dan tujuan ke depan dalam rangka menatap realitas masyarakat yang semakin gobal. Menurut pandangan Gorton ${ }^{22}$, kepala madrasah adalah agen pembaharu, sangat penting dalam inovasi pembelajaran yaitu untuk menilai efektivitas program, mengkaji, mengembangkan dan mengimplementasikan program pengembangan madrasah.

Menurut Rogers, beberapa langkah, tugas kepala madrasah Madrasah Aliyah Negeri 2 Probolinggo sebagai pemimpim visioner pada lembaga pendidikan dalam upaya memperkenalkan inovasi adalah sebagai berikut : 1) membangkitkan kebutuhan untuk berubah, tahap ini kepala madrasah sebagai pemimpin visioner membantu klien dapat menemukan masalah-masalah penyelesaiannya. 2) memantapkan hubungan pertukaran informasi. Karena itu kepala sebagai pemimpin visioner harus segera membina hubungan dengan klien, dan adanya saling kepercayaan. 3) Mendiagnosa masalah yang dihadapi. Kepala madrasah sebagai pemimpin visioner harus melihat masalah dengan kaca mata klien, artinya kesimpulan diagnosa harus berdasarkan analisa situasi dan psikologi klien, bukan berdasarkan pandangan pribadi kepala madrasah. 4) Mengembangkan kemampuan klien untuk berubah. Kepala madrasah sebagai pemimpin visioner bertugas untuk mencari cara memotivasi dan menarik perhatian klien agar timbul kemauannya untuk berubah.

Sedangkan factor-faktor yang mempengaruhi terhadap pelaksanaan proses kepemimpinan kepala madrasah sebagai pemimpin visioner pada lembaga pendidikan, khususnya pendidikan yang berlangsung di Madrasah Aliyah, menurut Ibrahim $^{23}$, ada beberapa factor yang mempengaruhi terhadap keberhasilan pemimpin visioner, diantaranya : Kegigihan pemimpin, menyesuaikan dengan kebutuhan klien, adanya kontak dengan klien, empati terhadap klien, memberi kepercayan kepada klien, hidari adanya professional semu, mendayagukan pemuka pendapat dan

${ }^{21}$ Ahmad Fauzi, 'Pengembangan Human Relation Perspektif Nilai-Nilai Al-Qur'an', (Mutawatir UIN Sunan Ampel Surabaya, 1.2, 2015), h. 168-79.

${ }^{22}$ Gorton R.A, School Administration Challenge and Opportunity for Leadership, (New York, Win C. Brown Company Publisher, 1976), h 215.

23 Ibrahim, Inovasi Pendidikan, (Depdikbud Dikti, Proyek Pengembangan Tenaga Pendidikan, Jakarta, 1998), h.115. 
menumbuhkan kemampuan klien untuk menilai inovasi ${ }^{24}$. Sebagai pemimpin visioner pada lembaga pendidikan Islam, kepala madrasah harus disertai dengan berbagai macam keterampilan dalam mengelola berbagai hal yang berkaitan proses pelaksanaan kepemimpinannya. Dalam hal ini, ada tiga macam keterampilan yang harus dimiliki oleh kepala madrasah untuk menyukseskan kepemimpinannya. Ketiga keterampilan tersebut adalah keterampilan konseptual, yaitu keterampilan untuk memahami dan mengoperasikan organisasi; keterampilan manusiawi, yaitu keterampilan untuk bekerja sama, memotivasi dan memimpin; serta keterampilan tekhnik adalah keterampilan dalam menggunakan pengetahuan metode, tekhnik, serta perlengkapan untuk menyelesaikan tugas tertentu.

Lebih lanjut dikemukakan bahwa untuk memiliki kemampuan, terutama keterampilan konsep, para kepala madrasah diharapkan melakukan kegiatankegiatan berikut : 1) senantiasa belajar dari pekerjaan sehari-hari terutama dari cara kerja para guru dan pegawai madrasah lainnya, 2) melakukan obeservasi kegiatan manajemen secara terencana, 3) membaca berbagai hal yang berkaitan dengan kegiatan-kegiatan yang sedang dilaksanakan, 4) memanfaatkan hasil-hasil penelitian orang lain, 5) berfikir untuk masa yang akan datang, 6) merumuskan ide-ide yang data diujicobakan. Selain itu, kepala madrasah harus dapat menerapkan gaya kepemimpinan yang efektf sesuai dengan situasi dan kebutuhan serta motivasi para guru dan pekerja lain ${ }^{25}$.

\section{Penutup}

\section{Kesimpulan}

Keberhasilan dan kegagalan suatu oganisasi banyak ditentukan oleh pemimpin karena pemimpin merupakan pengendali dan penentu arah yang hendak ditempuh oleh organisasi menuju tujuan yang akan dicapai, mengingat pentingnya pemimpin dalam sebuah lembaga pendidikan madrasah, maka seorang pemimpin harus memiliki standar dalam melaksanakan proses kepemimpinannya. Diantara standar kompetensi yang di miliki kepala Madrasah Aliyah Negeri 2 Probolinggo, antara lain: pertama, General life skill yang mencakup Personal skill, Thinking skill dan Social skill. Kedua, Spesific life skill yang mencakup; Academic skill dan Vocational skill. Kompetensi tersebut merupakan kerangka dasar yang harus dimiliki dalam rangka menciptakan proses pelaksanaan kepedidikan yang efektif dan efisien, mewujudkan tujuan dari lembaga pendidikan yang dipimpinnya, memperbaiki dan mengangkat mutu, kualitas dan citra Madrasah Aliyah, dan dapat mengcover terhadap berbagai kebutuhan konsumen yang berkaitan dengan lembaga pendidikan yang dipimpinnya.

24 Ahmad Fauzi, 'Organizational Culture of Islamic Public Education Management a Discurtive', in International Conference On Islamic Education (ICIED) Innovations, Approaches, Challenges, And The Future (Malang: Fakultas Ilmu Tarbiyah dan Keguruan UIN Maulana Malik Ibrahim Malang, 2017), pp. 130-36.

${ }^{25}$ E. Mulyasa, Manajemen Berbasis Sekolah : Konsep, Strategi dan Implementasi, (Bandung, PT Remaja Rosdakarya, 2004), h.126-127. 
Setiap kepala madrasah, khususnya Kepala Madrasah Aliyah Negeri 2 Probolinggo dibutuhkan kompetensi dan skill yang bersifat universal dan kompetensi atau skill yang bersifat khusus yang harus dimiliki. Kompetensi atau skill yang bersifat universal, meliputi; kemampuan dasar, sifat atau watak; sedang persyaratan khusus yang diperlukan berbagai kemampuan, seperti penguasaan terhadap tugas dan keterampilan profesional, serta pelatihan dan pengalaman professional dan kompetensi administrasi dan pengawasan. Demikian kepala Madrasah Aliyah Negeri 2 Probolinggo sebagai pemimpin visioner yang berorientasi ke depan, apa yang ingin diwujudkan di masa depan dari realitas yang sedang dihadapi yang akan melakukan lima peran; pertama, peran merumuskan visi (the vision role); kedua, peran menjalin hubungan (the relationship roles); ketiga, peran mengendalikan (the control role); keempat, peran melakukan dorongan (the encourage role); kelima, Peran sebagai pemberi informasi (the information role). 


\section{DAFTAR PUSTAKA}

Anthony-Darden-Bedford, 1992, Sistem Pengendalian Manajemen, Jilid 1, Jakarta, Bina Rupa Aksara.

Fauzi, Ahmad, 'Diskursus Pemikiran Dan Model Pengembangan Budaya Organisasi Noble Industry Di Lembaga Pendidikan Islam', Studi Islam Madinah IAI Tabah, $16(2016)$

_- 'Human Resource Management Dalam Meningkatkan Mutu Dosen PTKIS', At-Ta'lim INZAH Genggong Probolinggo, 4, 1 (2018), 21-34

__, 'Manajemen Pendidikan Islam Di Pesantren; Berbasis Kearifan Lokal Kajian Fenomenologis', in Seminar Nasional Pendidikan, Fakultas Ilmu Pendidikan Universitas Negeri Malang Sinergitas Keluarga, Sekolah Dan Masyarakat Dalam Penguatan Pendidikan Karakter (Malang, 2017), pp. 51-62

_- 'Membangun Epistemologi Pendidikan Islam Melalui Kepemimpinan Spiritual : Suatu Telaah Diskursif', Empirisma STAIN Kediri, 24 (2015), 155-67

- 'Model Manajemen Pendidikan Islam; Telaah Atas Pemikiran Dan Tindakan Sosial', At-Ta'lim INZAH Genggong Probolinggo, 4 (2017), 1-16

-, 'Organizational Culture of Islamic Public Education Management a Discurtive', in International Conference On Islamic Education (ICIED) Innovations, Approaches, Challenges, And The Future (Malang: Fakultas Ilmu Tarbiyah dan Keguruan UIN Maulana Malik Ibrahim Malang, 2017), pp. 130-36

_ UIN Sunan Ampel Surabaya, 1 (2015), 168-79

_ Interaksionalisme Simbolik', Al-Tahril IAIN Ponorogo, 17 (2017), 105-32

Stephen P. Robbins, 1996, Prilaku Organisasi: Konsep, Kontroversi, Aplikasi, Jilid 1, Jakarta, PT. Prehallindo.

Stephen P. Robbins, 2002, Prinsip-Prinsip Prilaku Organisasi, Jakarta, Erlangga.

Robert B. Maddux, 2001, Team Building, alih bahasa oleh Kristiabudi P. Hananto, Team Building: Terampil Membangun Tim Handal, Jakarta, Erlangga.

Wahjosumidjo, 2002, Kepemimpinan Kepala Sekolah Tinjauan Teoritik dan Permasalahannya, Jakarta, PT Raja Grafinco Persada.

Muhaimin, 2005, Pengembangan Kurikulum Pendidikan Agama Islam di Sekolah, Madrasah dan Perguruan Tinggi, Jakarta, PT Raja Grafindo Persada. 
Sondang P. Siagian, tt, Organisasi Kepemimpinan dan Perilaku Administrasi, Jakarta,Gunung Agung.

Y.W Sunindhia \& Ninik Widiyanti, 1993, Kepemimpinan dalam Masyarakat Modern, Jakarta,Rineka Cipta.

Piet A. Sahertian, 1994, Dimensi Aministrasi Pendidikan, Surabaya, Usaha Nasional.

Sondang P. Siagian, 2004, Manajemen Strategik, Jakarta, Bumi Aksara.

Hendiyat Soetopo \& Wasty Soemanto, tt, Kepemimpinan dalam Pendidikan, Surabaya, Usaha Nasional.

H.A.R Tilaar, 2000, Paradigma Baru Pendidikan Nasional, Jakarta, Rineka Cipta.

Ngalim Purwanto, 1991, Administrasi Pendidikan, Jakarta, Mutiara Sumber Widya.

Tri Darmayanti, dalam In Service Training $M T s / M i$, Depag RI Basic Education Project (BEP) PPIM IAIN Jakarta.

Gorton R.A, 1976, School Administration Challenge and Opportunity for Leadership, New York, Win C. Brown Company Publisher.

Ibrahim, 1998, Inovasi Pendidikan, Depdikbud Dikti, Proyek Pengembangan Tenaga Pendidikan, Jakarta.

E. Mulyasa, 2004, Manajemen Berbasis Sekolah : Konsep, Strategi dan Implementasi, Bandung, PT Remaja Rosdakarya. 